\title{
Microbiological analysis of surfaces in a surgical center: Identification and bacterial activity against antibiotics and disinfectant
}

\author{
Análise microbiológica de superfícies em um bloco cirúrgico: identificação e atividade \\ bacteriana frente antibióticos e desinfetante
}

\author{
Fabíola Dresch, Claudete Rempel, Mônica Jachetti Maciel \\ Centro Universitário UNIVATES \\ fdresch@universo.univates.br; crempel@univates.br; monicajm@univates.br
}

\begin{abstract}
The objective was to identify the microbiota present on hospital rooms surfaces of a surgical center, to know the susceptibility of the bacteria to antimicrobials and to evaluate the bacterial activity against the disinfectant commonly used in the hospital routine. This is a cross-sectional, descriptive study with a quantitative approach. The samples were collected from surfaces in different environments of the surgical center including admission room, recovery room and operating rooms. The microorganisms were identified and after the isolation, the antimicrobial susceptibility test was performed by the disc-diffusion method. The antimicrobial activity of the disinfectant was evaluated by the quantitative suspension test. Twenty-four areas were analyzed, 15 (62.5\%) presented microbial contamination, and 35 strains with a coagulase-negative Staphylococcus coagulase (69\%) were isolated, followed by S. saprophyticus (23\%), Acinetobacter sp. (6\%) and E. coli (2\%). Of these, 51\% had resistance to at least one antibiotic, and Staphylococcus methicillin resistant strains were found. The tested disinfectant showed proven antimicrobial activity. The antimicrobial action of the disinfectant was proven, but the presence of microorganisms evidences the importance of hygienic care in order to avoid the recurrence of contamination after cleaning.
\end{abstract}

Keywords: Operating Rooms. Disinfectant. Hospital management. Cross Infection

\section{Resumo}

O objetivo foi identificar a microbiota presente em superficies hospitalares de salas de um centro cirúrgico, conhecer a susceptibilidade das bactérias aos antimicrobianos e avaliar a atividade bacteriana frente ao desinfetante comumente utilizado na rotina hospitalar. Trata-se de um estudo transversal, descritivo com abordagem quantitativa. As amostras foram coletadas de superficies em diferentes ambientes do centro cirúrgico incluindo sala de admissão, sala de recuperação e salas cirúrgicas. Os microrganismos foram identificados e após o isolamento, realizou-se o teste de sensibilidade aos antimicrobianos pelo método de disco-difusão. A atividade antimicrobiana do desinfetante foi avaliada pelo teste de suspensão quantitativo. Analisou-se 24 superficies, 15 (62,5\%) apresentaram contaminação microbiana, sendo isoladas 35 cepas com prevalência de Staphylococcus coagulase negativa (69\%), seguido de S. saprophyticus (23\%), Acinetobacter sp. (6\%) e E. coli (2\%). Dessas, 51\% apresentaram resistência a, no mínimo, um antibiótico, sendo encontradas cepas de Staphylococcus meticilina resistente. $O$ desinfetante testado apresentou atividade antimicrobiana comprovada. A ação antimicrobiana do desinfetante foi comprovada, porém a presença de microrganismos evidencia a importância de cuidados de higienização para evitar a reincidência da contaminação após a limpeza.

Palavras-chave: Salas cirúrgicas. Desinfetante. Gestão hospitalar. Infecção Hospitalar 


\section{Introduction}

Even with many advances in the medical field, healthcare-associated infections (HAIs) are still considered a serious public health problem, due to their high morbidity and mortality rates (ROSENTHAL; GUZMAN; ORELLANO, 2003). Among the HAIs, the surgical site infection (SSI) is one of the main morbidities occurring in the hospital environment in Brazil, staying among the three most frequent infections, representing $14 \%$ to $16 \%$ of those found among hospitalized patients, prolonging thus, the length of hospital stay (BRASIL, 2009). In addition, SSIs are directly related to the causes of death of patients in the postoperative period. According to Centers for Disease Control and Prevention (CDC), in 1999, 77\% of deaths were associated with infections, and the majority (93\%) involved severe infections of organs and spaces manipulated during surgery (MANGRAM et al., 1999).

The SSI is an inherent complication of the surgical procedure. Its incidence is associated with multiple factors. These include the health conditions of the patient, the surgical procedure, and the type of microorganism that causes it. The origin of the causative microorganisms may be endogenous, originating from the flora of the patient, or exogenous (MANGRAM et al., 1999; YEZLI; BARBUT; OTTER, 2014). In relation to the exogenous sources of infection, the contamination of the hospital environment, including that of inanimate surfaces, contributes to the multiplication, dissemination and transmission of pathogens of great clinical relevance directly related to cases of infections, and can be transmitted through cross contamination of health professionals, through contact with surfaces frequently handled before contact with the patient or working instruments (YEZLI; BARBUT; OTTER, 2014; BHALLA et al., 2004).

Therefore, adequate processes of cleaning and disinfection of surfaces become indispensable for the control and minimization of contamination (YEZLI; BARBUT; OTTER, 2014; BREATHNACH, 2013). Nevertheless, for efficient disinfection, it is necessary to evaluate several factors involved in the choice of the disinfectant, since inadequate disinfection processes are associated with the development of resistant strains (BREATHNACH, 2013). On this account, although the inadequate and excessive use of antibiotics is still one of the main reasons for the development of resistant microorganisms (BRASIL, 2013), there are other factors that may also contribute to microbial resistance, among them is the reduced efficacy of disinfectants (LANGSRUD SUNDHEIM, BORGMANNSTRAHSEN, 2003).

The surveillance of antimicrobial resistance is vital to guide the empirical treatment of infections. The collection and dissemination of routine data on isolated clinical tests may provide more opportune information on the resistance patterns than the traditional methods of surveillance network (SAVAGE et al., 2016).

Thus, in order to know the microbiological profile of surfaces in a surgical ward, the present study aims to: analyze hospital rooms surfaces of the surgical center of a hospital in the countryside of the State of Rio Grande do Sul, identify the microbiota present in the sites, know the susceptibility of the bacteria found against antimicrobials, and evaluate the bacterial activity against the disinfectant commonly used in the hospital routine.

\section{Method}

This is a cross-sectional descriptive study with a quantitative approach that sought to evaluate microbial samples collected on the surfaces of rooms of a surgical ward in a small hospital in the countryside of Rio Grande do Sul, Lajeado, RS, Brazil, at 2015. 
The hospital has a medium level of complexity and has 79 beds, two operating rooms, a recovery room and does not have an intensive care unit (ICU). In order to evaluate the surgical center settings, the admission room, two operating rooms and a recovery room were analyzed. The hygiene of rooms always occurs after each patient leaves. At the time of collection, all environments had already been sanitized and were ready to receive patients.

The sampled surfaces were different in each analyzed room and were chosen because they are surfaces on which more manipulation occurs by health professionals. A table used by nurses, a headboard, a faucet and the door handle were analyzed in the admission room. In the operating rooms, keyboards, computer mouses, armrest supports, and tables of anesthetist and nurses use, and tables of surgical materials were analyzed. In the recovery room were analyzed: telephone, keyboard, computer mouse, computer desk, stretcher rails and faucet.

For the collection of the microorganisms, swabs in Stuart medium were used, which were pressed on the sampled surfaces, stored in the transport medium contained in the swab and placed in a suitable thermal box for the transportation to the Laboratory of Didactic Microbiology, of Univates in order to initiate the microbiological analyzes.

The isolation and the bacterial identification were performed according to the methodologies of the Manual of the National Agency of Sanitary Surveillance (ANVISA) (BRASIL, 2013). Strains of the same bacterial species, if found on the same surface, were characterized by the colony morphology and by the antimicrobial susceptibility.

After the identification of the microorganisms, the antimicrobial susceptibility test was performed by the agar disc diffusion method according to the standardization of the Clinical Laboratory Standards Institute (CLSI) (CLSI, 2014). The selection of the tested antibiotics varied according to the classification of the microorganisms, that is, in Gram-positive and Gram-negative (LABORCLIN, 2013). The microorganisms that showed resistance to antibiotics were submitted to the antimicrobial activity evaluation test of disinfectant. For the gram-positive bacteria, the $1 \mu \mathrm{g}$ oxacillin sensitivity or resistance result was reported based on the $30 \mu \mathrm{g}$ cefoxitin test result. Based on these characteristics, it was possible to verify if the bacterium referred to is the methicillin-resistant Staphylococcus type (MRS) (CLSI, 2014; LABORCLIN, 2013).

The methodology for evaluating the antimicrobial activity of disinfectant was carried out using the quantitative suspension test based on the European Standard - EN: 1040:2005 at a contact time of 5, 10 and 15 minutes12. The antimicrobial activity was certified with a reduction of at least $5 \log$ in the counting colonies (BS, 2006).

The disinfectant used in the hospital and tested in the study was the product Optigerm ${ }^{\circledR}$ (General Clean, Brasil), composed of polyhexamethylene biguanide (PHMB) and a mixture of alkydimethylbenzylammonium chloride with didecyldimethylammonium chloride, used on surfaces and non-critical articles.

For the expression of the results, a descriptive analysis of the data was carried out, using absolute numbers and percentage data of the microorganisms found on the hospital surfaces and of the performed tests, using Excel calculation spreadsheet, 2010.

\section{Results}

Among the 24 sampled surfaces, 15 (63\%) presented microbial contamination, and of them, six (40\%) had a growth of more than one bacterial species. The admission room and surgery room 1 were the environments with the highest number of contaminated surfaces, only one of the surfaces sampled at each site did not show bacterial growth. 
Among the surfaces, the table of materials, the table of the anesthetist, the telephone and the keyboards were the places that presented contamination in all the rooms where they were analyzed.

Thirty-five strains were found, and the most prevalent bacterium was coagulase negative Staphylococcus (CNS) ( $\mathrm{n}=24)$, followed by $S$. saprophyticus $(\mathrm{n}=8)$, Acinetobacter $\mathrm{sp}$. $(\mathrm{n}=2)$, and E. coli $(\mathrm{n}=1)$, the amount in $\%$ is indicated in Figure 1.

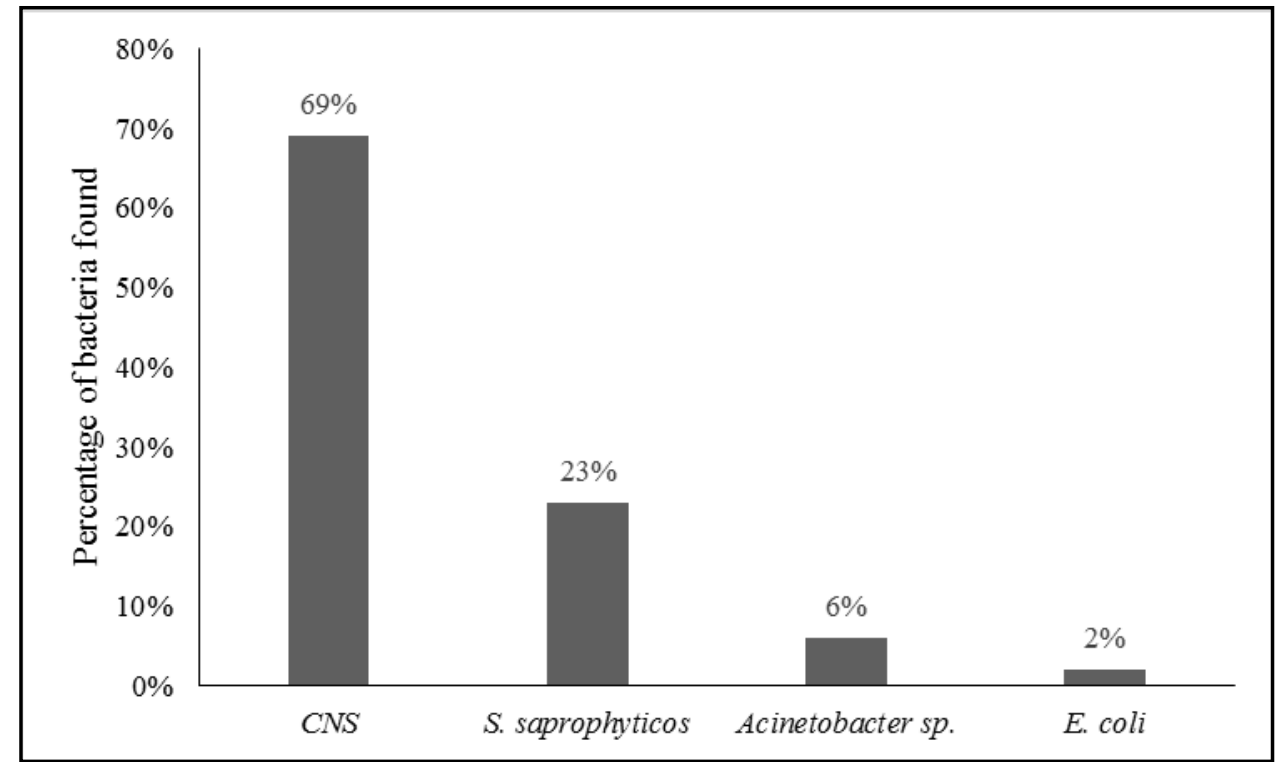

Figure 1. Frequency (\%) of the bacteria found on the surfaces analyzed in the different rooms of the surgical center of a hospital in the countryside of Rio Grande do Sul

Table 1. Species of bacteria found on the surfaces analyzed in the different rooms of the surgical center of a hospital in the countryside

\begin{tabular}{|c|c|c|c|c|c|}
\hline Local & Admission room & Operating room 1 & Operating room 2 & Surgical Ward & Recovery room \\
\hline Door handle & 0 & - & - & - & - \\
\hline Nurse's table & $\begin{array}{c}\text { CNS } \\
\text { S.saprophyticus }\end{array}$ & $\mathrm{CNS}$ & 0 & - & - \\
\hline Faucet & $\begin{array}{c}\text { CNS } \\
\text { S.saprophyticus }\end{array}$ & - & - & - & 0 \\
\hline Headboard & $\begin{array}{c}\text { CNS } \\
\text { S.saprophyticus }\end{array}$ & - & - & - & - \\
\hline Mouse & - & 0 & 0 & - & $\mathrm{CNS}$ \\
\hline Table for material & - & Acinetobacter sp. & $\mathrm{CNS}$ & - & - \\
\hline Anesthetist's table & - & CNS & $\mathrm{CNS}$ & - & - \\
\hline Keyboard & - & $\mathrm{CNS}$ & $\begin{array}{c}\text { CNS } \\
\text { S.saprophyticus }\end{array}$ & - & $\begin{array}{c}\text { CNS } \\
\text { S.saprophyticus }\end{array}$ \\
\hline Armrest support & - & $\mathrm{CNS}$ & 0 & - & - \\
\hline Bed rail & - & - & - & 0 & 0 \\
\hline Telephone & - & - & - & $\begin{array}{c}\text { CNS } \\
\text { Acinetobacter } \\
\text { sp. E.coli }\end{array}$ & $\mathrm{CNS}$ \\
\hline Computer desk & - & - & - & - & 0 \\
\hline
\end{tabular}

0: No microbial growth; -: Microbiological test not performed; CNS: Coagulase negative Staphylococcus 
The species of bacteria found on each sampled surface, according to the respective rooms, are presented in Table 1. There were surfaces that presented different strains of the same species, these were differentiated by the morphology and by their susceptibility to antimicrobials.

The antimicrobial susceptibility test was performed with the 35 strains, and a total of 18 (51\%) presented resistance to, at least, one antibiotic. Of these, $12(67 \%)$ were resistant to one antibiotic and six (33\%) presented resistance to two antimicrobials.

Among the Gram-positive CNS, penicillin was the antibiotic to which the bacteria showed the highest resistance, 13 (54\%) resistant. Yet the S. saprophyticus strains were resistant just to clindamycin, where two (25\%) showed resistance.

In figure 2 it is possible to observe the resistance frequency of Gram-positive bacteria separated by species

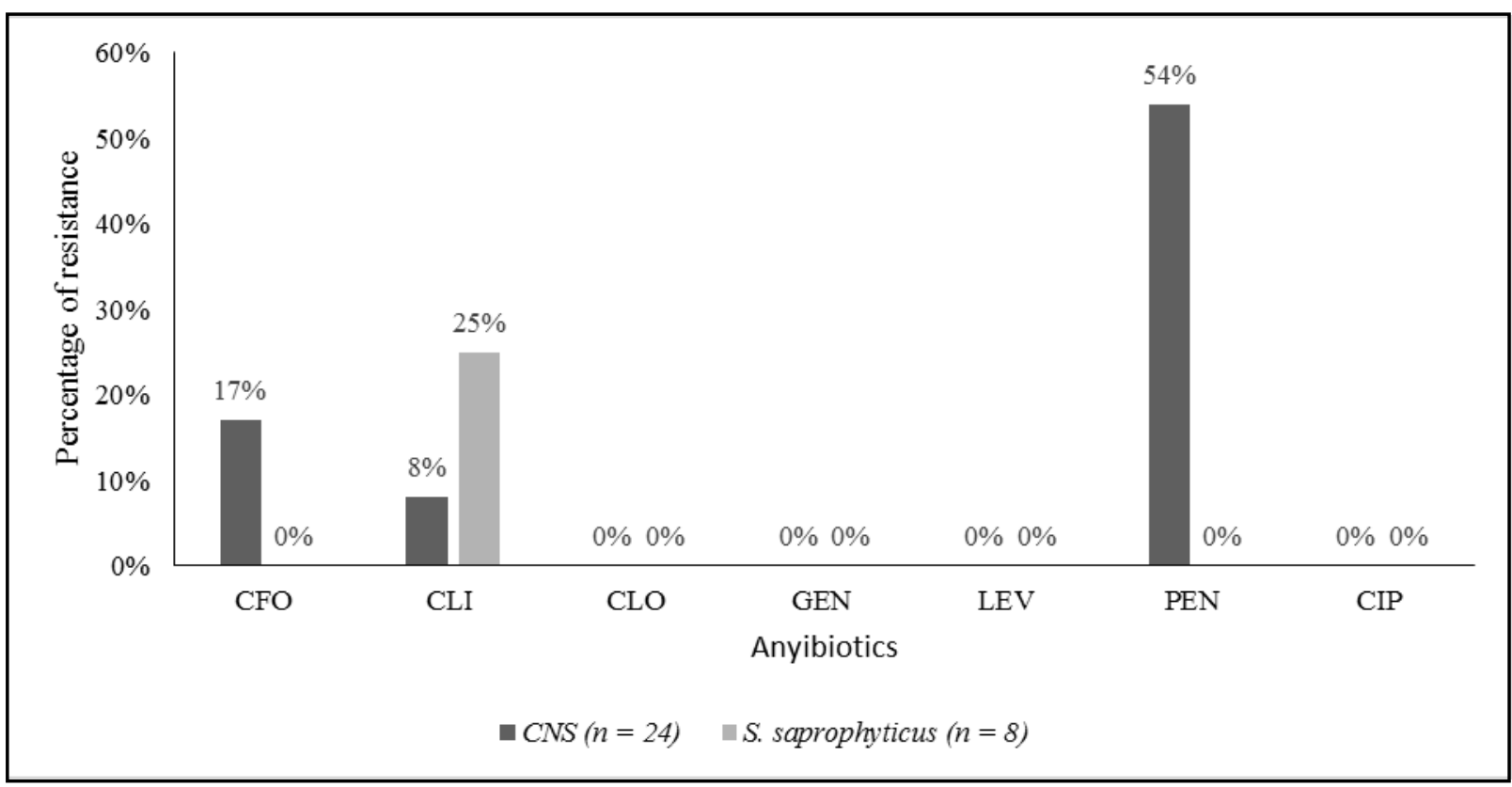

$\mathrm{CFO}=$ Cefoxitin $30 \mu \mathrm{g}$; CLI = Clindamycin $2 \mu \mathrm{g}$; CLO = Chloramphenicol $30 \mu \mathrm{g}$; GEN = Gentamicin $10 \mu \mathrm{g}$; LEV = Levofloxacin $5 \mu \mathrm{g}$; PEN = Penicillin $10 \mu \mathrm{g} ; \mathrm{CIP}=$ Ciprofloxacin $5 \mu \mathrm{g}$

Figure 2. Frequency (\%) of the resistance to antibiotics presented by the Gram-positive bacteria found on the analyzed surfaces of a hospital in the countryside of Rio Grande do Sul

The bacteria that showed resistance to the antibiotic cefoxitin $30 \mu \mathrm{g}$ were considered oxacillin-resistant because, according to the Clinical and Laboratory Standards Institute (CLSI, 2014), the result of the sensitivity or resistance of oxacillin $1 \mu \mathrm{g}$ should be based on the result of the test with cefoxitin $30 \mu \mathrm{g}$. However, the penicillin and cefoxitin discs are used to predict the sensitivity of the bacterium to all beta-lactams. Therefore, Staphylococcus sp., penicillin and oxacillin resistant are resistant to all beta-lactam antibiotics (CLSI, 2014). Gentamicin has been increasingly used instead of cephalosporins for surgical prophylaxis in an attempt to reduce the infection rate by Clostridium difficile (SRISUNG et al., 2017). 
In this study, all resistant coagulase negative Staphylococcus (CNS) presented resistance to penicillin. And four of them (31\%) presented, simultaneously, resistance to oxacillin, and it is possible to characterize them as methicillin-resistant Staphylococcus (MRS).

According to figure 3, the three Gram-negative bacteria found were resistant to cefatzidime and just E.coli showed resistance to more than one antibiotic.

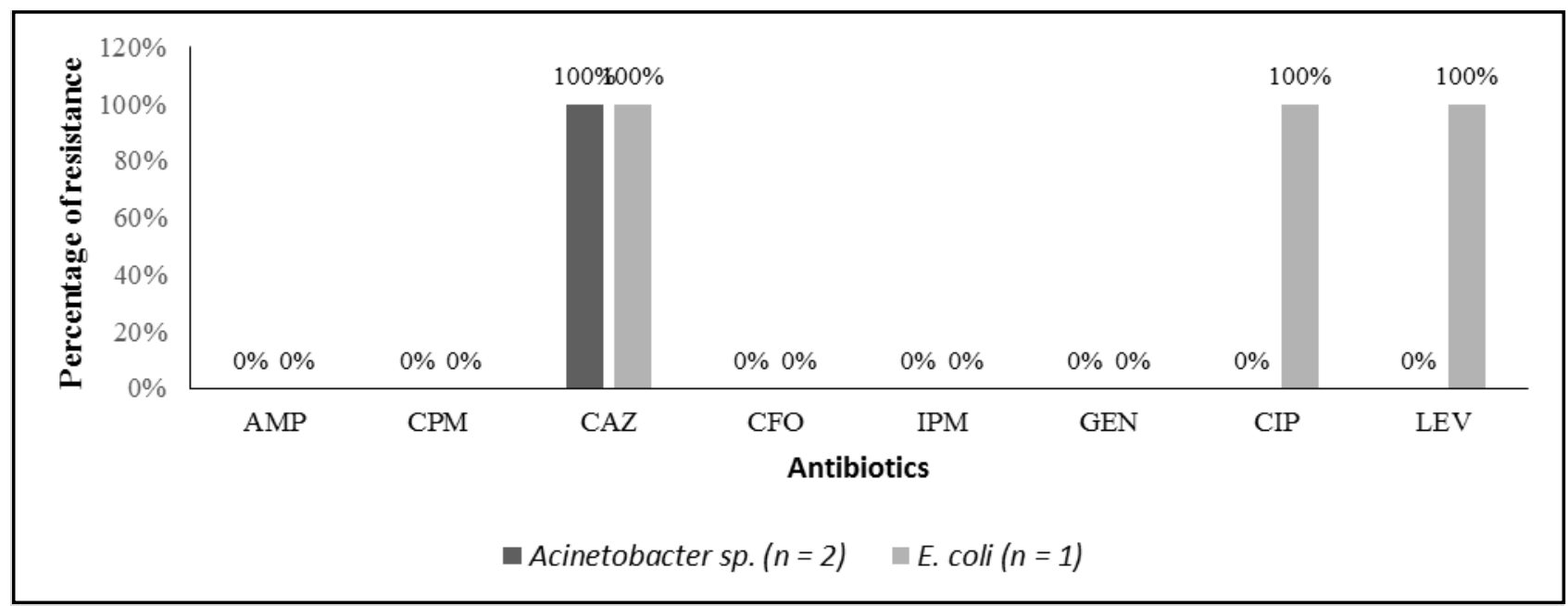

$\mathrm{AMP}=$ Ampicillin; $\mathrm{CPM}=$ Cefepime $30 \mu \mathrm{g} ; \mathrm{CAZ}=$ Ceftazidime $30 \mu \mathrm{g} ; \mathrm{CFO}=$ Cefoxitin $30 \mu \mathrm{g} ; \mathrm{IPM}=\mathrm{Imipenem} ; \mathrm{GEN}=\mathrm{Gentamicin} 10 \mu \mathrm{g} ; \mathrm{CIP}=$ Ciprofloxacin $5 \mu \mathrm{g}$; LEV $=$ Levofloxacin $5 \mu \mathrm{g}$.

Figure 3. Frequency (\%) of the resistance to antibiotics presented by the Gram-negative bacteria found on the analyzed surfaces of a hospital in the countryside of Rio Grande do Sul

For the evaluation of the antimicrobial activity of the disinfectant applied in the hospital, only strains that showed resistance to the antibiotics were used, and none of them presented bacterial growth after the contact times of 5 , 10 and 15 minutes.

\section{Discussion}

In the present study, $92 \%$ of the bacteria identified on the surfaces belonged to the genus Staphylococcus sp., all coagulase negative Staphylococcus (CNS), 23\% of them were identified as S. saprophyticus. This result is associated to the data found in another study regarding the contamination of surgical instrument tables (AMARAL et al., 2013), where CNS bacteria were also identified with higher frequency among the samples of Staphylococcus sp.. Besides being frequently cited in studies that aimed to analyze contamination of the hospital environment in general (ALEXANDER et al., 2013), even samples of patients (BHALLA et al., 2004, BARRETO; PICOLI, 2008). In the study by Savage et al. (2016) 1416 pathogens were isolated from 1202 patients, where the most common organisms were Escherichia coli (15.3\%), Staphylococcus aureus (12.4\%), CNS (8.3\%), Klebsiella pneumoniae (6.1\%), and Streptococcus pneumoniae (6.0\%).

Microorganisms of the genus Staphylococcus sp. are commonly found on the skin and mucous membranes, and can be easily transmitted by the team of professionals in the hospital environment, mainly by the upper airways and 
hands (BHALLA et al., 2004; BRASIL, 2013), contributing directly to the incidence of cross contamination of pathogens responsible for infections (YEZLI; BARBUT; OTTER, 2014; BHALLA et al., 2004; BARRETO; PICOLI, 2008). In the study by Bahlla et al. (2004), bacteria of clinical importance were found in the hands of health professionals after the contact with surfaces close to patients. The study by Alexander et al. (2013) evaluated the contamination of possible sites of infection in the operating rooms, reinforcing the important role of the surfaces as a reservoir of microorganisms, since it was observed that surfaces routinely used by the health team, such as tables, mouses and telephones, presented a higher bacterial colonization when compared to those that were not frequently handled, and Staphylococcus sp. was the main colonizing agent. Such evidences corroborate with the results shown in the present study, regarding the contaminated surfaces, that were also the places where there is more contact and handling by the health professionals.

Although CNS are not clinically relevant in community-acquired infections, since they are part of the normal microbiota of humans, they represent the second major causative agent of SSI in the hospital environment, after Staphylococcus aureus (AMARAL et al., 2013; ALEXANDER et al., 2013). Associated, more frequently, to urinary infections, infections related to permanent devices, endocarditis of natural and prosthetic cardiac valves, and postoperative osteomyelitis and endophthalmitis (BERNARDI; PIZZOLITTO; PIZZOLITTO, 2007). However, CNS bacteria acquire pathogenic potential only when exposed to a variety of factors, among them, microbial load, the patient's immunological status, and the treatment and procedures to which they are exposed, acting as opportunistic bacteria that cause infections (MANGRAM et al., 1999; BRASIL, 2013). Yet, the most important factor in the pathogenicity of CNS strains in the hospital environment is the acquisition of antimicrobial resistance (SANTOS, 2004).

The incidence of resistant CNS in the hospital environment, including patient samples, has been increasing gradually and is being cited by several authors (AMARAL et al., 2013; BARRETO, PICOLI, 2008), mainly to oxacillin, an antimicrobial used as the first choice for the treatment of resistant staphylococcal infections. This fact contributes to the selection and dissemination of resistant strains, and the use of other antimicrobials of broad spectrum is necessary (SANTOS, 2004). The present study confirms this data, presenting $16 \%$ of the strains of CNS found as methicillin-resistant Staphylococcus (MRS).

In reference to the strains of S. saprophyticus identified in this study, no studies were found specifically related to its incidence in the hospital environment, as well as in surgical centers. However, its growth cannot be ruled out, since in most studies only the CNS class is mentioned, they are not identified separately. The strains isolated in the research presented sensitivity to most of the antimicrobials, only two $(25 \%)$ of the eight strains were resistant to clindamycin. Its incidence may be related to the fact of being commonly found on the skin, not representing great clinical relevance in this case. However, for being part of the periurethral and mucosal microbiota of the urinary and genital tracts, it is frequently related to cases of urinary infection, already considered the second major cause of the pathology (HIRZEL, 2004).

Acinetobacter sp. is a typical microorganism of a hospital environment, mainly in the intensive care unit (ICU), where they are responsible for considerable mortality rates and, in most cases, presents multiresistance. Microorganisms of the genus Acinetobacter are able to survive for a long time on inanimate surfaces (URBAN; SEGAL-MAURER; RAHAL, 2003; WEBER et al., 2010). In the present study, its incidence was low if compared to Gram-positive bacteria, besides presenting high sensitivity to the tested antimicrobials, differing from other studies (URBAN; SEGAL- 
MAURER; RAHAL, 2003; WEBER et al., 2010). This can be explained by the fact that the place of research is a small hospital that does not have an ICU, and consequently, does not treat high risk patients where such microorganisms are found more frequently.

However, the presence of strains on the analyzed surfaces may contribute to the assertion that health professionals can be considered vehicles of contamination, since many of the professionals can perform their functions in other hospitals where there may be contact with Acinetobacter sp. strains, or even by the contact of infected patients transferred from another care unit (WEBER et al., 2010). In addition, this fact reinforces the need of hygiene care so that such strains cannot be disseminated affecting patients and causing serious infections (BHALLA et al., 2004; BREATHNACH, 2013). The same refers to the E. coli strain found, indicating a possible cross-contamination, since they are more restricted bacteria to environmental/fecal contamination, often associated with infections of abdominal surgeries (BREATHNACH, 2013).

In relation to the surface disinfection, the European Committee for Standardization protocol (CEN) (BS, 2006) states that, in order to demonstrate the efficacy of the disinfectant, the reduction in the population density of the inoculum is necessary in, at least, five log units after time of contact with the bactericidal agent. The disinfectant tested in this study showed a proven antimicrobial activity (BS, 2006), inhibiting the growth of microorganisms with a population density of $107 \mathrm{CFU} / \mathrm{mL}$ in the three analyzed contact times. The time of exposure of the surfaces to the environment after cleaning may have influenced their contamination, since more than 30 minutes had passed from the last cleaning and the last patient had been discharged from the room. Enough time to occur contamination, since according to the study of Loftus et al. (2008), who evaluated the transmission of pathogens during the anesthesia process, 4 minutes can be enough for the anesthetist's work area to become contaminated. The circulation of professionals in surgical rooms, considering the opening of the doors, contributes directly to the dispersion of microorganisms by air (LYNCH et al., 2009). In this way, cleaning is necessary after the end of one surgery and minutes before the next one, because in this period of time, the surfaces are subject to contamination, due to the circulation and the contact of the health professionals team and the contamination of the Air of the environment, in which microorganisms are present, even of great clinical importance (BARRETO; PICOLI, 2008). Thus, cleaning is necessary after the end of a surgery, and some minutes before the next one, because in this period of time, the surfaces are at risk of contamination, due to the circulation and the contact of the health professionals team, and the contamination of the air in the environment, in which microorganisms are present, even of great clinical importance (BARRETO; PICOLI, 2008).

The results allow us to infer that the evaluation of the microbial load of surfaces is useful in the investigation of possible sources of contamination, since the surfaces of the analyzed surgical center can be considered reservoirs of microorganisms of clinical relevance already related to SSI (YEZLI; BARBUT; OTTER, 2014; BHALLA et al., 2004; AMARAL et al., 2013), as CNS bacteria, the main pathogen found on the evaluated surfaces, contributing to the occurrence of cross-contamination (BHALLA et al., 2004).

The SCN is a microorganism present in the normal skin and mucosal microbiota (BRASIL, 2013) and oxacillin-resistant strains are being frequently found in the hospital environment and in cultures of patients diagnosed with SSI (AMARAL et al., 2013; BARRETO; PICOLI, 2008). However, it is worth emphasizing that, in order for the disease to occur, other factors need to be evidenced besides the direct contact with the pathogen, among them we can include the exposed microbial load, the immunological status of the patient, the treatment, and the procedures to which 
they are exposed to, besides the antibiotic resistance capacity that the bacterium can present (MANGRAM et al., 1999; BRASIL, 2013).

\section{Conclusions}

The surfaces analyzed in this study showed microbial contamination, mainly of Staphylococcus sp. bacteria with predominance of CNS, which are directly related to cross-contamination, becoming a risk to patients. Regarding to the antimicrobial resistance, the presence of MRS strains in the evaluated sites evidences the potential for resistance that CNS can acquire.

There were no results of simultaneous resistance between antibiotics and disinfectants, but the presence of Enterobacteria in the study indicates a greater care and attention to proper cleaning, because even if the disinfectant has had its microbial activity proven, measures of hand hygiene and care regarding the process of cleaning and disinfection are necessary, evaluating the time of exposure of the surface, in order to avoid the recurrence of microbial contamination.

In this case, we have to highlight the importance of further studies to quantify the role of contamination in cases of infection, correlating it with episodes of hospital infections. Besides the realization of other collections for further research of different sources of contamination, with the aim to identify possible sites and think of viable strategies to interrupt or minimize the risks of cross contamination among patients, environment and professionals.

\section{References}

ALEXANDER JW, VAN SWERINGEN H, VANOSS K, HOOKER EA, EDWARDS MJ. Surveillance of bacterial colonization in operating rooms. Surgical infections. 2013;14(4):345-351.

AMARAL AM, DIOGO FILHO A, SOUSA MM, BARBOSA PA, GONTIJO FILHO PP. The importance of protecting surgical instrument tables from intraoperative contamination in clean surgeries. Revista LatinoAmericana de Enfermagem. 2013;21(1):426-432.

BARRETO MF, PICOLI SU. Staphylococcus in a hospital in Porto Alegre (RS). Revista Brasileira de Análises Clínicas. 2008;40(4):285-287.

BERNARDI, Adilson César Abreu; PIZZOLITTO, Elisabeth Loshchagin; PIZZOLITTO, Antonio Carlos. Detecção da produção de slime por estafilococos coagulase-negativa isolados de cateter venoso central. Rev. Ciênc. Farm. Básica Apl. 2007;28(1):57-66.

BHALLA A, PULTZ NJ, GRIES DM, RAY AJ, ECKSTEIN EC, ARON DC et al. Acquisition of nosocomial pathogens on hands after contact with environmental surfaces near hospitalized patients. Infection Control \& Hospital Epidemiology. 2004;25(2):164-167.

BRASIL. Agência Nacional de Vigilância Sanitária (ANVISA). Microbiologia Clínica para o Controle de Infecção Relacionada à Assistência à Saúde. Módulo 6: Detecção e identificação de bactérias de importância médica. 1 ed. Brasília: Anvisa. 2013.

BRASIL. Agência Nacional de Vigilância Sanitária (ANVISA). Sítio cirúrgico: Critérios Nacionais de Infecções relacionadas à assistência à saúde. Brasília: Anvisa. 2009. Disponível em: http://www.anvisa.gov.br/servicosaude/manuais/criterios_nacionais_ISC.pdf. 
BREATHNACH AS. Nosocomial infections and infection control. Medicine. 2013;41(11):649-653.

BS - British Standard. The European Standard EN 1040:2005 has. Chemical disinfectants and antiseptics quantitative - suspencion test for the evaluation of basic bactericidal activity of chemical desinfectants and antiseptics -Test method and requerements (phase 1), 2006.

CLSI - Clinical and Laboratory Standards Institute. Performance Standards for Antimicrobial Susceptibility Testing: Twenty-Fourth Informational Supplement. M100 S-24.2014;34(1). Disponível em: http://ncipd.org/control/images/NCIPD_docs/CLSI_M100-S24.pdf

HIRZEL W. Implicancias del Staphylococcus saprophyticus en la patología infecciosa urinaria de la mujer. Acta Bioquímica Clínica Latino Americana [online]. 2004;38(2):217-222.

LABORCLIN. Manual do Antibiograma; 2013. 32 p. Disponível em http://www.interlabdist.com.br/dados/noticias/pdf_238.pdf

LANGSRUD S, SUNDHEIM G, BORGMANN-STRAHSEN R. Intrinsic and acquired resistance to quaternary ammonium compounds in food-related Pseudomonas spp. J Appl Microbiol. 2003;95:874-882.

LOFTUS RW, KOFF MD, BURCHMAN CC, SCHWARTZMAN JD, THORUM V, READ ME, WOOD TA, BEACH ML. Transmission of pathogenic bacterial organisms in the anesthesia work area. Anesthesiology. 2008;109(3):399-407.

LYNCH RJ, ENGLESBE MJ, STURM L, BITAR A, BUDHIRAJ K, KOLLA S et al. Measurement of foot traffic in the operating room: implications for infection control. American Journal of Medical Quality. 2009;24(1):45-52.

MANGRAM AJ, HORAN TC, PEARSON ML, SILVER LC, JARVIS WR. Guideline for prevention of surgical site infection, 1999. Infection control and hospital epidemiology. 1999;20(4):247-278.

ROSENTHAL VD, GUZMAN S, ORELLANO PW. Nosocomial infections in medical-surgical intensive care units in Argentina: attributable mortality and length of stay. American Journal of Infection Control. 2003;31(5): 291-295.

SANTOS NQ. A resistência bacteriana no contexto da infecção hospitalar. Texto Contexto Enfermagem. 2004;13(n.esp):64-70.

SAVAGE RD, FOWLER RA, RISHU AH, BAGSHAW SM, COOK D, DODEK P et al. Pathogens and antimicrobial susceptibility profiles in critically ill patients with bloodstream infections: a descriptive study. CMAJ Open. 2016; 4(4):E569-E577.

SRISUNG W, TEERAKANOK J, TANTRACHOTI P, KARUKOTE A, NUGENT K. Surgical prophylaxis with gentamicin and acute kidney injury: a systematic review and meta-analysis. Ann Transl Med. 2017;5(5):100

URBAN C, SEGAL-MAURER S, RAHAL J. Considerations in control and treatment of nosocomial infections due to multidrug-resistant Acinetobacter baumannii. Clinical Infectious Diseases. 2003;36(10):1268-1274.

WEBER DJ, RUTALA WA, MILLER MB, HUSLAGE K, SICKBERT-BENNETT E. Role of hospital surfaces in the transmission of emerging health care-associated pathogens: norovirus, Clostridium difficile, and Acinetobacter species. American Journal of Infection Control. 2010;38(5 Suppl 1):25-33.

YEZLI S, BARBUT F, OTTER JA. Otter. Surface contamination in operating rooms: a risk for transmission of pathogens? Surgical infections. 2014;15(6):694-69. 